\title{
Influența lui Darwin asupra filosofiei ${ }^{\dagger}$
}

\author{
John Dewey
}

I

Că publicarea Originii speciilor a marcat o etapă în dezvoltarea științelor naturii, acesta este un fapt bine cunoscut omului obişnuit. Că îmbinarea, anume, a cuvintelor origine și specie a dat expresie unei revolte intelectuale și a introdus un nou cadru de gîndire, acesta este însă un fapt prea lesne trecut cu vederea de către expert. Concepțiile care domniseră în filosofia naturii și a cunoașterii timp de două mii de ani, concepțiile care deveniseră recuzita familiară a minții se sprijineau pe presupunerea superiorității celor fixe și finale, se sprijineau pe considerarea schimbării și a originii drept semne ale imperfecțiunii și ale nonrealității. Atingînd chivotul sacru al permanenței absolute, tratînd formele, care fuseseră privite ca tipuri ale imobilității și perfecțiunii, drept lucruri care se nasc și pier, Originea speciilor a introdus un mod de gîndire care, în cele din urmă, avea să transforme logica cunoașterii și, în consecință, tipul de abordare a moralei, a politicii şi a religiei.

$\mathrm{Nu}$ este, deci, de mirare că apariția cărții lui Darwin, acum o jumătate de secol, a provocat o criză. Totuşi, adevărata natură a controversei ne scapă cu ușurință din cauza strigătului de indignare teologică ce a însoțit-o. Trăsăturile vii și populare ale zarvei anti-darwiniste au tins să lase impresia că problema se găsea între știință, pe de o parte, și teologie, pe de altă parte. Nu era cazul! Chestiunea ținea, în principal, de știință, după cum Darwin însuși recunoscuse de timpuriu. Cît despre protestul teologic, pe acesta el l-a nesocotit de la bun început, abia luîndu-l în seamă, și numai în măsura în care avea vreun efect asupra „sentimentelor rudelor de sex feminin”. Însă, timp de două decenii, înainte de publicarea cărții, el a tot cîntărit posibilitatea de a fi catalogat drept prost sau nebun de către confrații din domeniu și, ca măsură a succesului său, a stabilit gradul în care trebuia să-i afecteze pe trei oameni de știință: Lyell în geologie, Hooker în botanică și Huxley în zoologie.

Considerațiile de ordin religios au adăugat tensiune controversei, dar nu ele au produs-o. Intelectual vorbind, emoțiile religioase nu sînt creatoare, ci conservatoare. Se asociază fără ezitare la viziunea curentă asupra lumii și o consfințesc. Ele doar înmoaie și vopsesc pînzele intelectuale în vasul clocotitor al emoțiilor; nu-și formează propria fibră și textură. $\mathrm{Nu}$ există, bănuiesc, niciun exemplu de idee grandioasă referitoare la lume care să fi fost generată de religie în mod independent. Deși ideile care s-au ridicat împotriva darwinismului asemeni unor oameni înarmaţi şi-au datorat intensitatea lor asocierilor religioase, originea și sensul lor trebuie căutate în știință și filosofie, nu în religie.

\section{II}

Puține cuvinte ale limbii noastre rezumă istoria intelectuală la fel de bine precum o face cuvîntul specie. Vechii greci, punînd bazele vieții intelectuale din Europa, erau impresionaţi de trăsăturile caracteristice ale vieții plantelor şi animalelor; într-adevăr, atît de impresionați, încît au făcut din aceste trăsături cheia către definirea naturii și către explicarea minții și a societății. Și, pe bună dreptate, viața este atît de minunată, încît o descifrare aparent reușită a tainei sale putea prea bine să conducă oamenii spre credința conform căreia cheia către secretele cerului și ale pămîntului se afla în mîinile lor. Felul grecesc de a înfățișa acest mister, formularea grecească a scopului cunoașterii și a standardului acesteia și-au găsit expresia, de-a lungul timpului, în cuvîntul specie,

${ }^{\dagger}$ O prelegere din cadrul unui curs de prelegeri publice pe tema Charles Darwin and His Influence on Science [Charles Darwin și influența sa asupra științei], ținut la Universitatea Columbia în timpul iernii și primăverii anului 1909. Prezenta traducere a fost efectuată de Cristinel Munteanu după versiunea reprodusă în John Dewey, The Influence of Darwin on Philosophy, and Other Essays in Contemporary Thought, Henry Holt and Company, New York, 1910, p. 1-19, CrossRef. Pentru verificări, a fost consultată și varianta „definitivă” inclusă în John Dewey, The Middle Works, 1899-1924, Volume 4: 1907-1909, Edited by Jo Ann Boydston, With an Introduction by Lewis E. Hahn, Southern Illinois University Press, 2008, p. 3-14. Traducătorul dorește să le mulțumească aici Profesorului Larry A. Hickman, Director of the Center for Dewey Studies, și doamnei Angela Moore-Swafford, Rights \& Permissions Manager of Southern Illinois University Press, pentru acordarea dreptului de a publica prezenta traducere românească. 
controlînd filosofia vreme de două mii de ani. Pentru a înțelege răsturnarea intelectuală redată de sintagma Originea speciilor, trebuie să înțelegem ideea îndelung dominantă împotriva căreia se constituie ca protest.

Gîndiți-vă la felul în care oamenii erau impresionați de faptele de viață. Ochii lor se opreau asupra anumitor lucruri oarecum nediferențiate și fragile în structură. Atît cît se putea observa, aceste lucruri percepute erau inerte și pasive. Deodată, în anumite împrejurări, lucrurile respective-cunoscute, din acel moment, ca semințe sau ouă sau germeni-încep să se schimbe, să-și modifice repede dimensiunea, forma și calitățile. Schimbări rapide și majore au loc, totuşi, în cazul multor lucruri-ca atunci cînd lemnul vine în contact cu focul. Însă schimbările din lucrurile vii sînt ordonate, sînt cumulative; tind, în mod constant, spre o singură direcție; nu distrug, sau nu consumă, sau nu se pierd sterile într-o curgere capricioasă, cum se întîmplă cu alte schimbări; ele realizează și îndeplinesc. Fiecare fază următoare, oricît de diferită ar fi față de precedenta, păstrează efectul net al acesteia și, totodată, pregătește terenul pentru o activitate mai împlinită din partea celei care îi urmează. În ființele vii, schimbările nu se produc cum par că se petrec oriunde altundeva, într-o totală indiferență; schimbările anterioare sînt aranjate în vederea rezultatelor ulterioare. Această organizare progresivă nu încetează pînă cînd nu este atins un adevărat termen final, un $\tau \varepsilon \lambda \dot{o} \varsigma$, un scop încheiat și desăvîrșit. O atare formă finală exercită, la rîndu-i, o multitudine de funcții, dintre care nu trebuie neglijată cea a producerii germenilor identici celor care i-au generat, germeni capabili de același ciclu al autoîndeplinirii.

Dar miraculoasa poveste nu a fost spusă pînă la capăt. Aceeași dramă este jucată pe baza aceluiași destin în cazul nenumăratelor mulțimi de indivizi atît de separați în timp, atît de despărțiți în spațiu, încît nu au nicio șansă pentru a se consulta reciproc şi niciun mijloc pentru a interacționa. După cum zicea, cu un farmec aparte, un bătrîn scriitor, „lucrurile de același fel trec prin aceleași formalități”- —sărbătoresc, cum s-ar zice, aceleaşi rituri ceremoniale.

Această activitate formală care operează printr-o întreagă serie de schimbări și le ține într-un singur curs, care subordonează curgerea lor fără de scop propriei sale manifestări perfecte, care, trecînd peste limitele spaţio-temporale, păstrează într-un tipuniform ca structură și funcție-indivizii distanțați în spațiu și depărtați în timp: acest principiu a pă- rut că oferă o privire pătrunzătoare în chiar natura realităţii înseși. Aristotel i-a dat numele de eĩoos. Termenul acesta a fost tradus de scolastici prin species.

Forța acestui termen a sporit prin aplicarea sa la orice lucru din univers care se supune curgerii ordonate și manifestă statornicie de-a lungul schimbării. De la variația normală a vremii de zi cu zi, prin repetarea neregulată a anotimpurilor și revenirea inegală a perioadelor pentru semănat și recoltat, pînă la maiestoasa limpezire a cerurilor-imaginea eternității în timp—şi, de la aceasta, pînă la inteligența neschimbătoare pură și contemplativă de dincolo de natură se întinde o împlinire neîntreruptă de țeluri. Natura ca întreg este o realizare progresivă a scopului, strict comparabilă cu realizarea scopului în orice plantă sau animal în parte.

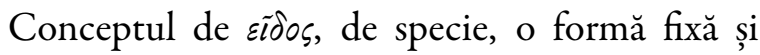
o cauză finală în același timp, constituia principiul cunoașterii și, totodată, al naturii. Pe el se baza logica științei. Schimbarea ca shimbare este simplă curgere şi alunecare; insultă inteligența. A cunoaşte în mod autentic înseamnă să captezi un scop permanent care se realizează pe sine prin schimbări, ținîndu-le pe acestea, tocmai de aceea, în limitele și granițele adevărului stabil. A cunoaște în mod desăvîrşit înseamnă să legi toate formele speciale de țelul și binele lor unic: inteligența contemplativă pură. Totuși, de vreme ce scena naturii care ni se înfățișează nemijlocit este în schimbare, natura, așa cum o experimentăm direct şi practic, nu satisface condițiile cunoașterii. Experiența umană este curgătoare şi, în consecință, instrumentele percepției senzoriale şi ale inferenţei bazate pe observație sînt condamnate dinainte. Știința este silită să țintească la realități aflate îndărăt și dincolo de procesele naturale și să persiste în căutarea acestor realităţi cu ajutorul formelor raționale care transcend modurile obişnuite de a percepe și de a judeca.

Există, într-adevăr, doar două căi alternative. Ori trebuie să descoperim obiectele şi organele potrivite ale cunoașterii în interacțiunile reciproce ale lucrurilor schimbătoare; ori, pentru a scăpa de infecția schimbării, trebuie să le căutăm pe acestea într-o regiune cumva transcendentă și celestă. Mintea omenească, în mod conștient, a epuizat mai întîi logica lucrurilor neschimbătoare, finale și transcendente, înainte să încerce să se aventureze pe terenul nestrăbătut al generării și al transformării. Ne lipsim mult prea lesne de eforturile vechilor cărturari de a interpreta natura și mintea în termenii esențelor reale, ai 
formelor ascunse și ai facultăților oculte, uitînd de caracterul serios și de demnitatea ideilor din spatele lor. Ne lipsim de ele rîzînd de faimosul gentleman care a explicat faptul că opiul îi adormea pe oameni pe temeiul că acesta ar fi avut o facultate dormitivă. Dar doctrina, susţinută și în zilele noastre, conform căreia cunoașterea plantei care produce semințele de mac constă în raportarea trăsăturilor unui individ la un tip, la o formă universală, o doctrină atît de puternic încetățenită, încît orice altă metodă de a cunoaște era considerată ca fiind nefilosofică și neștiințifică, este o supraviețuire a exact aceleiași logici. Această identitate de concepție în cazul teoriei scolastice și al celei anti-darwiniste ar putea sugera destul de bine o mai mare simpatie pentru ceea ce a devenit nefamiliar, precum şi o mai mare modestie cu privire la viitoarele chestiuni nefamiliare pe care istoria le ține spre păstrare.

Darwin nu a fost, desigur, cel dintîi care s-a îndoit de filosofia clasică a naturii și a cunoașterii. Începuturile revoluției se găsesc în știința fizicii din secolele al XVI-lea și al XVII-lea. Cînd Galileo a spus: „Sînt de părere că Pămîntul este foarte nobil și vrednic de toată admirația din pricina modificărilor și generărilor atît de numeroase și atît de diferite care au loc aici fără încetare", el a dat expresie acelei schimbări de perspectivă care venea asupra lumii: transferul interesului dinspre ceea ce este permanent către ceea ce este schimbător. Cînd Descartes a spus: „Natura lucrurilor fizice este mult mai ușor de conceput atunci cînd acestea sînt privite ca luînd ființă treptat, decît atunci cînd sînt considerate doar ca fiind produse, dintr-o dată, într-o stare perfectă și încheiată”, lumea modernă a devenit conștientă de logica ce avea să o controleze din acel moment încolo, logica pentru care Originea speciilor a lui Darwin reprezintă cea mai recentă realizare științifică. Fără metodele lui Copernicus, Kepler, Galileo și ale urmașilor acestora în astronomie, fizică și chimie, Darwin ar fi fost neputincios în științele organice. Dar, înaintea lui Darwin, impactul noii metode științifice asupra vieții, minții și politicii fusese blocat, fiindcă între aceste interese ideale și morale și lumea anorganică a intervenit regnul animalelor și al plantelor. Porţile de la grădina vieții erau zăvorîte în fața noilor idei; și numai prin această grădină se putea trece către minte și politică. Influența lui Darwin asupra filosofiei rezidă în reușita sa de a fi cucerit fenomenele vieții în contul principiului tranziției și, prin urmare, de a fi eliberat logica nouă, pentru a fi aplicată și la minte, și la morală, și la viață. Cînd el a spus despre specii ceea ce Galileo spusese despre Pămînt, e pur se muove, a emancipat, odată pentru totdeauna, ideile genetice și experimentale ca organon al punerii de întrebări și al căutării de explicaţii.

\section{III}

Foloasele exacte ale noii perspective logice pentru filosofie sînt, firește, pînă acum, nesigure și incipiente. Trăim în zorii tranziției intelectuale. Cineva ar trebui să adauge imprudența profetului la încăpățînarea partizanului pentru a risca o expunere sistematică a influenței metodei darwiniste asupra filosofiei. Cel mult, putem să examinăm implicația sa generalăefectul asupra cadrului mental și asupra punctului de vedere global, asupra acelui ansamblu de simpatii şi de antipatii intelectuale, pe jumătate conștiente, pe jumătate instinctive, care determină, în cele din urmă, acțiunile noastre intelectuale mai deliberate. În această cercetare vagă se întîmplă să existe, ca un fel de de piatră de încercare, o problemă cu o îndelungată circulație istorică, ce a fost, de asemenea, mult discutată în literatura darwinistă. Mă refer la vechea problemă a planificării opuse întîmplării, a minții opuse materiei, ca explicație cauzală, primă sau finală, a lucrurilor.

După cum am văzut deja, noțiunea clasică de specie purta cu sine ideea de scop. În toate formele de viață se găsește un model specific care direcționează primele faze ale creșterii spre realizarea propriei perfecțiuni. Întrucît acest principiu ordonator finalist nu poate fi perceput de simțuri, rezultă că trebuie să fie o forță rațională sau ideală. Totuși, de vreme ce forma perfectă este aproximată în mod treptat printre schimbările sensibile, rezultă, tot așa, că o forță ideală rațională își îndeplinește propria manifestare supremă într-un tărîm sensibil. Aceste raționamente au fost extinse la nivelul naturii: (a) Ea nu face nimic în zadar, ci totul pentru un scop ulterior. (b) În cadrul evenimentelor naturale sensibile se află, deci, cuprinsă o forță spirituală cauzală, care, spirituală fiind, scapă percepției, însă este intuită de o rațiune iluminată. (c) Manifestarea acestui principiu atrage după sine o subordonare a materiei și a simțirii față de propria realizare și această împlinire ultimă reprezintă ținta naturii și a omului. Astfel, argumentul planificării opera în două direcții. Însușirea de a avea un scop explica inteligibilitatea naturii și posibilita- 
tea științei, în timp ce caracterul absolut sau cosmic al acestei calități finaliste conferea legitimare și valoare năzuințelor morale și religioase ale omului. Știința era fundamentată și morala era autorizată în baza unuia și aceluiași principiu, iar acordul lor reciproc era garantat pe vecie.

Această filosofie a rămas, în ciuda unor izbucniri sceptice și polemice, filosofia oficială și dominantă a Europei vreme de mai bine de două mii de ani. Izgonirea cauzei prime și a celei finale din astronomie, fizică și chimie îi provocase doctrinei, într-adevăr, un fel de șoc. Dar, pe de altă parte, familiarizarea sporită cu detaliile vieții plantelor și a animalelor a acționat ca o contrabalanță și, probabil, a și întărit argumentul planificării. Adaptările uimitoare ale organismelor la mediul lor, ale organelor la organism, ale părților diferite ale unui organ complex-cum este ochiulla organul însuși; prefigurarea formelor superioare prin cele inferioare; pregătirea, în faze mai timpurii ale creșterii, pentru organe care abia mai tîrziu aveau să funcționeze-aceste lucruri erau din ce în ce mai recunoscute odată cu progresul botanicii, al zoologiei, al paleontologiei și al embriologiei. Adunate, ele au adăugat un asemenea prestigiu la argumentul planificării, încît, spre sfîrșitul secolului al XVIIIlea, acesta constituia, după cum consimțeau științele vieții organice, punctul central al filosofiei teiste și idealiste.

Principiul darwinist al selecției naturale a secționat fundamentele acestei filosofii. Dacă toate adaptările organice se datorează pur şi simplu variației constante și eliminării acelor variații care sînt dăunătoare în lupta pentru existență provocată de reproducerea excesivă, nu mai este nevoie de o forță anterioară cauzală și inteligentă care să le planifice și să le instituie dinainte. Criticii ostili l-au acuzat pe Darwin de materialism şi de faptul de a fi făcut din întîmplare cauza universului.

Unii naturaliști, precum Asa Gray, au dat întîietate principiului darwinist şi au încercat să-l împace cu ideea planificării. Gray a susținut ceea ce s-ar putea numi modelul bazat pe un plan „foileton”. Dacă am concepe „fluxul variaţiilor” ca fiind proiectat în sine, am putea presupune că fiecare variație succesivă a fost de la început configurată pentru a fi selectată. În acest caz, variația, lupta și selecția definesc, pur și simplu, mecanismul "cauzelor secundare” prin care acționează „cauza primă”; iar doctrina planificării nu ar fi cu nimic afectată, fiindcă știm mai multe despre al său modus operandi.

Darwin nu putea accepta o atare propunere de mediere. El admite sau, mai degrabă, afirmă că este „imposibil să ne imaginăm acest univers imens și minunat, incluzînd omul cu a sa capacitate de a privi departe în trecut sau departe în viitor, ca fiind rezultatul întîmplării oarbe sau al necesităţii” ${ }^{1}$. Cu toate acestea, el suține că, de vreme ce variațiile se desfășoară în direcții atît inutile, cît și utile și întrucît acestea din urmă sînt pur și simplu trecute prin sită de tensiunea condițiilor luptei pentru existență, argumentul planificării, aplicat ființelor vii, este nejustificabil; iar lipsa lui de temei în acea zonă îi știrbește valoarea științifică și cînd este aplicat la natură în general. Dacă variațiile porumbelului-care, în urma selecției artificiale, duc la porumbelul rotat—nu sînt preinstituite în interesul crescătorului, atunci în baza cărei logici vom argumenta că variațiile care rezultă în speciile naturale sînt planificate dinainte $?^{2}$.

\section{IV}

Cam atît în legătură cu faptele mai evidente ale discuției privind opoziția planificare-întîmplare, ca principii cauzale ale naturii și ale vieții în ansamblul lor. Am invocat această discuție, vă amintiți, ca o dovadă crucială. Ce indică piatra noastră de încercare în ceea ce privește relevanța ideilor darwiniste pentru filosofie? În primul rînd, logica nouă exilează, izolează, concediază—spuneți-i cum doriți-un tip de probleme și le înlocuiește cu un alt tip. Filosofia renunță la căutarea originilor absolute și a scopurilor absolute tocmai pentru a explora valorile specifice și condițiile specifice care le generează pe acestea.

Darwin a tras concluzia că imposibilitatea de a pune lumea ca întreg pe seama întîmplării și a părților sale pe seama planificării semnala caracterul insolubil al chestiunii. Totuşi, două motive radical diferite pot fi oferite pentru a arăta de ce o problemă este insolubilă. Un motiv ar fi acela că problema depășește capacitatea de înțelegere; celălalt motiv ar fi acela că întrebarea, în însuși procesul ei interogativ, face

${ }^{1}$ Life and Letters [Viață și scrisori], vol. I, p. 282; cf. 285.

${ }^{2}$ Life and Letters [Viață și scrisori], vol. II, p. 146, 170, 245; vol. I, p. 283-284. Vezi, de asemenea, secțiunea de încheiere din lucrarea sa Variations of Animals and Plants under Domestication [cf. Charles Darwin, Variațiile animalelor și plantelor sub influența domesticirii, Editura Academiei R.P.R., București, 1963]. 
presupuneri care o transformă în ceva fără sens. Cea de-a doua alternativă se vădește negreșit în faimosul caz al planificării opuse întîmplării. Odată ce am admis că singurul obiect verificabil sau productiv al cunoașterii este setul particular de schimbări care generează obiectul de studiu dimpreună cu consecințele care decurg din el, nicio întrebare inteligibilă nu mai poate fi pusă cu privire la ceea ce, prin presupunere, se găsește în afară. A afirma-cum se afirmă deseorică valorile specifice ale adevărului particular, ale legăturilor sociale și ale formelor de frumos, dacă pot fi dovedite ca fiind generate de condiții cognoscibile în mod concret, sînt fără noimă și zadarnice; a afirma că acestea sînt justificate doar atunci cînd ele şi cauzele lor, laolaltă cu efectele, au fost adunate dintr-o dată într-un fel de cauză primă integratoare și într-un fel de scop final atotcuprinzător denotă atavism intelectual. O atare argumentaţie reprezintă o reîntoarcere la logica aceea care explica stingerea focului cu apă grație esenței formale a acvaității și potolirea setei cu apă grație cauzei finale a acvaității . Întrebuințată fie în cazul unui eveniment special, fie în cazul vieții ca întreg, o asemenea logică nu face altceva decît să abstragă vreun aspect din cursul existent al evenimentelor pentru a-l reduplica apoi ca un principiu etern încremenit prin care să explice exact schimbările a căror formalizare o constituie.

Cînd Henry Sidgwick a remarcat întîmplător într-o scrisoare că, pe măsură ce îmbătrînea, interesul său pentru acel ceva sau cineva care a creat lumea se preschimba în interesul pentru ce fel de lume este în definitiv aceasta, modul în care el dădea glas unei experiențe comune a zilelor noastre ilustrează, totodată, natura transformării intelectuale produse de logica darwinistă. Interesul se mută dinspre esența general valabilă din spatele schimbărilor speciale spre întrebarea cum de reușesc schimbările speciale să servească și să învingă scopurile concrete; se mută dinspre o inteligență care a modelat lucrurile odată pentru totdeauna spre inteligențele particulare pe care lucrurile le modelează chiar și acum; se mută dinspre o țintă supremă a binelui spre îmbunătățirile nemijlocite ale dreptăţii şi ale fericirii pe care fie administrarea chibzuită a condițiilor existente le poate spori, fie nepăsarea sau prostia actuală le vor distruge ori le vor abandona.
În al doilea rînd, logica de tip clasic i-a fixat filosofiei, în mod inevitabil, sarcina de a dovedi că viața trebuie să aibă anumite calități și valori-indiferent de felul în care experiența prezintă materia-din pricina unei cauze îndepărtate și a unui scop final. Obligația justificării în bloc însoțește fără scăpare toată gîndirea care face ca sensul aparițiilor speciale să depindă de ceva care se găsește odată pentru totdeauna îndărătul lor. Obiceiul de a ne abate de la sensurile și utilizările actuale ne împiedică să înfruntăm direct faptele experienței; ne împiedică să recunoaștem în mod serios relele pe care acestea le prezintă și să ne preocupăm în mod serios de binele pe care îl promit, dar pe care nu îl împlinesc încă. Acest obicei sucește gîndul înspre problema găsirii unui remediu transcendent general valabil pentru unul și a găsirii unei garanții de același tip pentru altul. Ni se amintește felul în care mulți moraliști și teologi au salutat faptul că Herbert Spencer a admis existența unei energii incognoscibile din care au izvorît procesele fizice fenomenale externe și operațiunile conștiente interne. Doar pentru că Spencer a etichetat energia sa incognoscibilă cu numele de „Dumnezeu”, această bucățică expirată din binele metafizic a fost întîmpinată ca o concesie importantă și plină de recunoștință față de realitatea tărîmului spiritual. Dacă nu ar fi fost această deprindere puternic susținută de a căuta justificare pentru valorile ideale în ceea ce este îndepărtat şi transcendent, cu siguranță că această raportare a lor la un absolut incognoscibil ar fi fost disprețuită în comparație cu demonstrațiile experienței potrivit cărora energiile cognoscibile generează zilnic în preajma noastră valori inestimabile.

Înlăturarea acestei filosofii de tip generalist nu se va putea face, indubitabil, printr-o respingere pur logică, ci, mai degrabă, prin recunoașterea crescîndă a inutilității sale. Să fi fost de o mie de ori adevărat că opiul produce somnul datorită energiei sale dormitive, și tot nu ar fi înaintat, cîtuși de puțin, ca atare, nici inducerea somnului în cel obosit și nici revenirea la starea de veghe a celui intoxicat. Și chiar de s-ar demonstra pe cale dialectică de o mie de ori că viața, în totalitatea ei, este direcționată de un principiu transcendent către un scop final integrator, totuși adevărul și eroarea, sănătatea și boala, binele și răul, speranța și frica, în concretul lor, vor rămîne numai

\footnotetext{
*în engleză, John Dewey utilizează termenul aqueousness, pentru care nu am găsit un echivalent tocmai potrivit în limba română. Un termen (rar întîlnit) cum este cel de acvacitate apare doar în contexte referitoare la înot. În faţa posibilităţii de a apela la o structură ca „modul-de-a-fi-apă”, am optat, totuşi, pentru un termen mai transparent: acvaitate [n.tr.].
} 
ceea ce sînt şi unde sînt acum. Pentru a ne îmbunătăți educația, pentru a ne ameliora conduita, pentru a face politica noastră să avanseze, trebuie să recurgem la condițiile specifice ale generării.

În fine, logica nouă introduce responsabilitatea în viața intelectuală. Să idealizezi și să raționalizezi universul în general este, la urma urmelor, o mărturisire a inabilității de a stăpîni cursul lucrurilor care ne preocupă în mod specific. Cît timp omenirea a suferit de această neputință, ea a deplasat, firește, o povară a responsabilității, pe care nu putea să o poarte, pe umerii mai competenți ai cauzei transcendente. Dar, dacă privirea înlăuntrul condițiilor specifice ale valorii și înlăuntrul consecințelor ideilor este posibilă, atunci filosofia trebuie să devină, cu timpul, o metodă de localizare și de interpretare a conflictelor mai serioase care se manifestă în viața noastră și o metodă de a inventa modalități prin care să se ocupe de ele: o metodă de diagnosticare şi de prognosticare morală şi politică.

Pretenția de a formula a priori legile fundamentale ale universului este, prin natura sa, o pretenție care poate duce la dezvoltări dialectice complicate. Dar ea este, totodată, una care elimină exact aceste concluzii de la testarea experimentală, fiindcă, prin definiție, aceste rezultate nu prezintă nicio importanță în cursul detaliat al evenimentelor. Însă o filosofie care-și coboară pretențiile pînă la nivelul muncii de construire a ipotezelor legate de educația și de comportamentul minții individuale și sociale este, în consecință, supusă testării respective prin felul în care ideile pe care le propune funcționează în practică. Impunîndu-i-se să devină mai modestă, filosofia dobîndește astfel și responsabilitate.

Fără îndoială, se pare că am încălcat promisiunea implicită din observațiile mele anterioare și m-am transformat și în profet, și în partizan. Dar, anticipînd direcția transformărilor în filosofie ce urmează a fi prelucrate de genetica darwinistă și de logica experimentală, nu pretind să vorbesc decît în numele celor care respectă în mod conștient sau inconștient această logică. Nimeni nu poate nega, pe drept cuvînt, faptul că în prezent există două efecte ale felului darwinist de a gîndi. Pe de o parte, se fac multe eforturi sincere şi vitale de a revizui concepțiile noastre filosofice tradiționale în acord cu solicitările acestui fel de a gîndi. Pe de altă parte, există, la fel de sigur, o recrudescență a filosofiilor absolutiste; o declarare a unui tip de cunoaștere filosofică distinctă de cea a științelor, un tip de cunoaștere care ne dezvăluie un alt gen de realitate, diferită de cea spre care științele ne oferă acces; un apel de a merge prin intermediul experienței către ceva care trece în mod esențial dincolo de experiență. Această reacție afectează atît credințele populare și curentele religioase, cît și filosofiile tehnice. Însăși cucerirea științelor biologice de către noile idei i-a făcut pe mulți să proclame o despărțire explicită și rigidă a filosofiei de știință.

Ideile vechi cedează lent, fiindcă ele sînt ceva mai mult decît forme logice abstracte și categorii. Sînt deprinderi, predispoziții, atitudini de simpatie și de antipatie adînc înrădăcinate. Dincolo de aceasta, persistă convingerea-chiar dacă istoria ne-o arată a fi o iluzie-că toate întrebările pe care mintea omenească și le-a pus sînt întrebări la care se poate răspunde în termenii alternativelor pe care le prezintă chiar întrebările respective. Dar, de fapt, progresul intelectual are loc de obicei, pur și simplu, printr-o abandonare a întrebărilor laolaltă cu ambele alternative pe care le presupun acestea-o abandonare care derivă din vitalitatea lor tot mai scăzută și dintr-o schimbare a interesului imediat. Deci, nu le rezolvăm: trecem peste ele. Întrebările vechi se rezolvă dispărînd, evaporîndu-se, în timp ce întrebările noicorespunzînd schimbării de atitudine în ceea ce privește aspirațiile și preferințele-le iau locul. Neîndoielnic, cel mai mare dizolvant, din gîndirea contemporană, al vechilor întrebări, cel mai mare precipitant al noilor metode, al noilor intenții, al noilor probleme este acela produs de revoluția științifică ce și-a găsit punctul culminant în Originea speciilor. 